COVID-19 Dalgaları Arasında Kalp Damar Cerrahisi Hastalarının

Başvuru Şeklindeki Değişiklikler

\title{
Changes In Admission Types of Cardiovascular Surgical Patients Between Covid-19 Waves
}

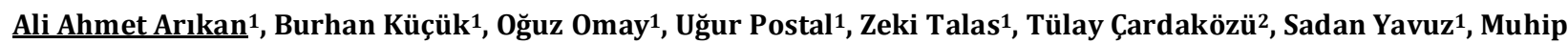
Kanko ${ }^{1}$

1Kocaeli Üniversitesi Tıp Fakültesi, Kalp Damar Cerrahisi Anabilim Dalı, Kocaeli, Türkiye

2Kocaeli Üniversitesi Tıp Fakültesi, Anesteziyoloji ve Reanimasyon Anabilim Dalı, Kocaeli, Türkiye

$\ddot{O} Z$

GİRiş ve AMAÇ: 2020 baharında 2019 koronavirüs hastalı̆ (COVID-19) artışı nedeniyle 75 günlük bir sokağa çıkma yasağ başladl. Acil olmayan tüm operasyonlar ertelendi. Pandeminin gerileme belirtileri ile tüm elektif vakalar yeniden bașladı. Bu, "yeni normal" dönemi ertelenmiş hizmetlerin telafi edilmesi açısından sağlık kurumları için benzersiz bir dönem olmuştur.

YÖNTEM ve GEREÇLER: 1 Haziran - 2 Kasim 2020 ("yeni normal" dönem) tarihleri arasinda kalp damar cerrahisi kliniğimizde COVID-19'u önlemek için alınan tedbirler ile başvuran hastaların özellikleri, yapılan cerrahi girişimlerin türlerine göre değerlendirildi ve 2017-2019 ylllarının aynı dönemine ait sonuçlar ile karşılaştırıldd.

BULGULAR: Önceki ylllara göre yeni normal döneminde acil operasyonlar arttı. $(p=0,042)$ Vasküler cerrahi acil operasyonlar $(p=0.029)$, plansız bașvurular $(p=0.017)$ ve hastaların Amerikan Anesteziyologlar Derneği $(A S A)$ skoru $(p=0.022)$ arttt. Kardiyak risk skoru $(p=.040)$, ASA skoru $(p<.001)$ ve pompasız koroner arter baypas greftleme (CABG) prosedürleri artarken ( $p$ $<.001)$, ameliyat sonrasi hastanede kalıs süresi azaldı $(p=.025)$. "Yeni normal" döneminin ilk yarısında, ikinci yarısına kyyasla anlamlı olarak daha fazla acil kalp cerrahisi ve damar cerrahisi (sirasiyla $p=.042, p=.004$ ) yapildl. Bilgisayarl tomografi kullanımı ve tespit edilen pnömoni önceki yillara göre iki kattan fazla arttı. Yatırllan hastaların \%1,74'ünde COVID-19 polimeraz. zincir reaksiyonu testi pozitifti.

TARTISSMA ve SONUÇ: Karantina döneminden sonra önceki yıllara kiyasla hasta risklerinde artış ve daha fazla acil ameliyat gereksinimi oluştuğu gözlendi. Acil damar ve kalp cerrahisi ameliyatlarının kisitlama tedbirlerinin kalkması sonrası ilk haftalara yı ̆̆ıldı̆̆g gözlendi.

Anahtar Kelimeler: kalp cerrahisi, damar cerrahisi, pandemiler, corona virüsü

\section{ABSTRACT}

INTRODUCTION: Due to the surge of coronavirus disease 2019 (COVID-19) in spring 2020, a 75-day lockdown began. All nonemergent operations, were postponed. With signs of resolution of the pandemic, all elective cases resumed. This represented a unique experience for health care providers to deal with at the beginning of the post-pandemic era, i.e., the "new normal."

METHODS: Patient characteristics, operations performed and diagnostic tools to prevent COVID-19 in our cardiovascular surgery clinic between June 1 and November 2, 2020 (the "new normal" period) were evaluated and compared with the results from the same period in 2017-2019.

RESULTS: Overall, emergency operations $(p=0.042)$ increased. Vascular surgery emergency operations $(p=0.029)$, unplanned admissions $(p=0.017)$, and the patients' American Society of Anesthesiologists (ASA) score $(p=0.022)$ increased. The cardiac risk score ( $p=.040)$, ASA score ( $p<.001)$, and off-pump coronary artery bypass grafting $(C A B G)$ procedures increased $(p<.001)$, while the postoperative hospital stays decreased $(p=.025)$ in the "new normal" period. In the first half of the "new normal" period, significantly more emergency heart surgical and vascular surgical procedures ( $p=.042, p=.004$, respectively) were performed compared with the second half. The use of computed tomography and detected pneumonia increased more than twofold compared to previous years. In relation to COVID-19, $1.74 \%$ of the admitted patients had a positive polymerase chain reaction test.

DISCUSSION AND CONCLUSION: An increase in patient risks and admission of more urgent cases was observed after the lockdown period,especially in the first weeks.

Keywords: cardiac surgery, vascular surgery, pandemics, corona virus
Iletişim / Correspondence:

Dr. Öğr. Üyesi Ali Ahmet Arıkan

Kocaeli Üniversitesi Tip Fakültesi, Kalp Damar Cerrahisi Anabilim Dall, Kocaeli,Türkiye

E-mail:dr_aarikan@hotmail.com

Başvuru Tarihi: 09.06.2021

Kabul Tarihi: 24.10.2021
Doi: $10.5505 / \mathrm{ktd} 2021.75002$

Sema Ali Ahmet Artkan: 0000-0002-9599-1577

Burhan Küçük: 0000-0002-6544-5639

Oğuz Omay: 0000-0001-8237-5137

Uğur Postal: 0000-0001-6124-4664

Zeki Talas: 0000-0001-6465-6170

Tülay Çardaközü: 0000-0002-4936-8020

Sadan Yavuz: 0000-0001-7566-5531

Muhip Kanko: 0000-0003-4339-2019 


\section{INTRODUCTION}

The ongoing coronavirus disease 2019 (COVID19) pandemic is affecting populations and health care systems worldwide. During the pandemic, "waves" in which the number of cases began to exceed health service capacity and the "new normal" periods when life became partially or completely normalized are new concepts that have entered our nomenclature.

On March 11, 2020, with the detection of the first case of COVID-19 in our country, to maximize total bed and intensive care unit (ICU) capacity and reduce the spread of the outbreak among our patients and health care providers, all non-urgent interventions, including cardiovascular surgery, were postponed in our university hospital, parallel to the government-declared restrictions on social life. The cardiovascular ICU is shared with all other surgical departments for postoperative care. Our hospital was one of the two centers of four stateowned training and research hospitals providing cardiovascular surgery services for emergencies during the pandemic in a city with a population of 2 million.

On 1 June 2020, a "new normal" period was declared by the Ministry of Health due to the reduction in COVID-19-infected patients. Our hospital's capacity returned to that of the prepandemic period. Treatment completion for previously diagnosed patients whose operations had been postponed and treatment of new symptomatic patients was our cardiovascular surgery clinic's goal in the "new normal" period. On November 2, 2020, a second COVID-19 wave forced us once again to halt elective operations. Despite developments in vaccination and treatment, due to the new variants of coronavirus, a single "new normal" could not be achieved, but attempts were made to provide usual health services between the COVID-19 waves. From this date, despite flattening of the curve of COVID-19 cases, our clinic's full capacity has not been reached again.

A backlog of operations that were postponed during the pandemic surge after a "wave" has potential consequences, such as hospital overcrowding and over-use of resources (1). Additionally, concerns about elective patients' change in status to urgent after lifting of the prohibitions have been reported (2). Moreover, newly diagnosed patients admitted in the "new normal" period will also be added to the patients waiting for care. A fall in numbers of cardiovascular surgical procedures during the surge in spring 2020 was reported in our region (3). However, the immediate opening of all elective procedures and outpatient clinics in our hospital in summer 2020 after a 75-day halt to non-urgent operations represented the beginning of the postpandemic era.

To elucidate the changes in this "new normal" period, we evaluated patient admission types and characteristics and compared them with the values of the same period during the three previous years. Our aim was to determine differences in the status of cardiovascular surgical patients in a single center. Evaluating the differences from the routine can help to plan for cardiovascular surgical patients after the COVID-19 waves.

\section{MATERIAL AND METHODS}

With approval from the institutional ethics committee (GOKAEK-2020/20.14) and the Ministry of Health (2020-11-17T12_53_38), this single-center retrospective cohort study included the patients who had undergone surgery in our clinic between June 1 and November 2 during the years 2017-2020. This period for the three years before the pandemic (2017-2019) is defined as "pre-pandemic," and the period between 1 June -2 November 2020 is defined as the "new normal" period. During the "new normal" period, masks were obligatory for patients and their attendants. Restriction of visits from the patients' visitors was recommended, but visitors were not banned. We checked the patients for symptoms, and a COVID19 polymerase chain reaction (PCR) test was performed on hospitalized patients at admission. If the operation was not performed within 24 hours of hospitalization, a second PCR test was taken the day before planned surgery. A computed tomography (CT) scan of the thorax was not routinely performed except in emergencies where the PCR test result was not known.

The age, gender, type of admission, type of surgery, duration of hospitalization, hospitalizations to ICU or ward, cardiac risk score, American Society of Anesthesiologists Classification (ASA) score, and in-hospital mortality were compared between the surgically treated patients in the prepandemic and "new normal" periods. Additionally, the total number and results of the PCR tests and CT scans of the thorax were investigated for all the patients, including the patients who did not underwent surgery. The CT scans were investigated for the diagnosis of pneumonia. Data were obtained from the hospital's electronic records and archive system. To evaluate the difference in admission rates, the "new normal" period was divided into two halves from August 15. 


\section{DEFINITIONS}

In this article, "heart surgery" refers to all kinds of open-heart surgery procedures and surgery of the thoracic aorta and pericardium. "Vascular surgery" refers to surgery of the abdominal aorta, vena cava, iliac arteries and veins, and all peripheral arterial surgical procedures for occlusive disease aneurysms or injuries. "Venous surgery" refers to varicose vein surgery, and "vascular access surgery" refers to arteriovenous fistula formation or central catheter insertion.

"Unplanned admission" refers to patients who were hospitalized with the code "urgent" as a result of their symptoms or critical lesions. "Emergency operation" refers to patients whose operations were coded as an emergency following a planned or unplanned admission and who were operated on due to ongoing symptoms or having a risk of death or limb loss. "Elective patient" refers to patients who had neither an unplanned admission nor an emergency operation. "Preop stay" is the duration from the patient's admission to the time of surgery. "Postop stay" is the duration of hospital stay after surgery, and "total stay" is the duration of hospitalization until discharge.

The cardiac risk score is based on EuroSCORE I and is required by the national insurance system and calculated for the operative risk assessment for heart surgery patients (4). It differs from the original score, as it excludes the parameters of unstable angina pectoris, recent myocardial infarction, neurologic dysfunction, emergency operation, and cardiac procedure other than or in addition to CABG (Table 1).

\section{STATISTİCAL ANALYSIS}

All statistical analyses were performed using SPSS for Windows version 20.0 (SPSS, Chicago, IL, USA). The Kolmogorov-Smirnov and ShapiroWilk tests were used to assess the assumption of normality. Numeric variables are presented with means \pm standard deviations and medians (25th75th percentiles). Categorical variables were summarized as counts (percentages). Since normality assumption did not hold, between-group comparisons of numeric variables were performed using the Mann-Whitney $\mathrm{U}$ test. Associations between two categorical variables were examined by the Chi-square test. All statistical analyses were carried out with 5\% significance, and a two-sided pvalue $<.05$ was considered statistically significant.

\section{RESULTS}

\section{PATIENT CHARACTERISTICS}

Between 2017 and 2020, 631 male and 414 female patients were operated on between June 1 and November 2. Of these, $62.3 \%(\mathrm{n}=651)$ were operated on under general anesthesia, 24.7\% $(\mathrm{n}=$ 258) under local anesthesia, and $13.0 \%(\mathrm{n}=136)$ under spinal anesthesia.

Among the patients operated on under general anesthesia, the ASA scores were ASA 1 for $17.0 \%$ $(\mathrm{n}=178)$, ASA 2 for $30.5 \%(\mathrm{n}=319)$, ASA 3 for $45.6 \%(\mathrm{n}=476)$, ASA 4 for $6.6 \%(\mathrm{n}=69)$, and ASA 5 for $0.3 \%(n=3)$.

The distribution of the procedures and the comparison between the pre-pandemic and the "new normal" periods is presented in Table 2 . The number of patients with ASA scores of 4 or 5 (p < $.001)$, unplanned ward admissions $(\mathrm{p}=.001)$, emergency operations $(\mathrm{p}=.042)$, and vascular surgery operations $(\mathrm{p}=.002)$ increased significantly in the "new normal" compared to the "prepandemic" period. Local procedures decreased significantly $(\mathrm{p}=.021)$.

The performed operations and their weight among major surgical procedures requiring postoperative ICU care is shown in Table 3 . In the 2017-2019 period, $67.4 \%$ of patients requiring ICU care were heart surgical patients compared to $56.3 \%$ of patients in 2020 . A $11.1 \%$ reduction in heart surgical operations was observed among patients requiring ICU in the "new normal" compared to the pre-pandemic period $(\mathrm{p}=.011)$.

A total of 2889 outpatient admissions were recorded in 2019, dropping to 1348 in the "new normal" period, despite the fact that elective admissions were accepted. The number of CT scans for in- and outpatients, the number with a noted presence of pneumonia, and the distribution of performed PCR tests are shown in Table 4.

Two patients in the heart surgery group who were operated on in the "new normal" period were COVID-19 survivors. Three heart surgical operations were postponed due to positive PCR tests. One embolectomy patient with atrial fibrillation had a positive PCR test. No COVID-19 related mortality was noted. 


\section{Table 1 The cardiac risk score (CRS)}

\begin{tabular}{|c|c|c|c|}
\hline \multicolumn{3}{|c|}{ Patient Characteristics } & $\frac{n}{\underline{L}}$ \\
\hline $1-$ & Age & $60-65$ years: $1,66-70$ years: 2 , more than 71 years $: 3$ points & \\
\hline $2-$ & Gender & Female & 1 \\
\hline 3- & Chronic pulmonary disease & $\begin{array}{l}\text { 1. Prescence of airway obstruction in respiratory } \\
\text { function test (F1/FVC } \% 70 \text { in altında) } \\
\text { ve/veya } \\
\text { 2. Low lung volume: } F V C<\% 80+F 1 / F V C>\% 70\end{array}$ & 1 \\
\hline 4- & Extracardiac arteriopathy & $\begin{array}{l}\text { Any one or more of the following: claudication, carotid } \\
\text { occlusion or }>50 \% \text { stenosis, previous or planned intervention } \\
\text { on the abdominal aorta,limb arteries or carotids }\end{array}$ & 2 \\
\hline $5-$ & Previous cardiac surgery & Requiring opening of the pericardium & 3 \\
\hline 6- & Renal impairment & $\begin{array}{l}\text { Serum Creatinin }>2.26 \mathrm{mg} / \mathrm{dl} \text { ve/or Glomerular Filtration Rate } \\
<60 \mathrm{ml} / \mathrm{min} \text {. }\end{array}$ & 2 \\
\hline $7-$ & Dialysis (if yes do not calculate line 6) & Patient on dialysis program & 5 \\
\hline $8-$ & Active endocarditis & $\begin{array}{l}\text { Endocarditis diagnosed by echocardiography and/or blood } \\
\text { cultures }\end{array}$ & 3 \\
\hline 9- & Critical preoperative state & $\begin{array}{l}\text { Preoperative cardiac massage, and/or prescence of intraaortic } \\
\text { baloon countrpulsation }\end{array}$ & 3 \\
\hline $10-$ & Diabetes Mellitus & Diabetes Mellitus requering insülin therapy & 2 \\
\hline \multicolumn{4}{|c|}{ Cardiac Factors } \\
\hline $11-$ & LV Dysfunction & An ejection Fraction between $\% 30-\% 50$ on Echocardiography & 1 \\
\hline $12-$ & & An ejection Fraction between $<\% 30$ on Echocardiography & 3 \\
\hline $13-$ & Pulmonary hypertension & Systolic Pulmonary arterial pressure $>40 \mathrm{mmHg}$ & 2 \\
\hline \multicolumn{4}{|c|}{ Operative Factors } \\
\hline $14-$ & Surgery on thoracic aorta & Surgery on thoracic aorta & 4 \\
\hline $15-$ & Postinfarct septal rupture & Dignosed by echocardiography or heart catheterisation & 5 \\
\hline
\end{tabular}

The score is the sum of points given in the table. 


\begin{tabular}{|c|c|c|c|c|c|c|c|}
\hline & $\begin{array}{c}2017 \\
(\mathrm{n}) \\
\end{array}$ & $\begin{array}{c}2018 \\
(\mathrm{n}) \\
\end{array}$ & $\begin{array}{c}2019 \\
(\mathrm{n}) \\
\end{array}$ & $\begin{array}{c}2017-2019 \\
(\mathrm{n}, \%)\end{array}$ & $\begin{array}{l}2020 \\
(\mathrm{n}, \%) \\
\end{array}$ & differance & $\mathrm{p}$ \\
\hline Female & 81 & 100 & 138 & $40.3 \%$ & $95,37.5 \%$ & $-2.8 \%$ & \multirow[t]{2}{*}{0.461} \\
\hline Male & 149 & 154 & 170 & $59.7 \%$ & $158,62.5 \%$ & $+2.8 \%$ & \\
\hline Age & $58(46-67)$ & $61(49-69)$ & $59(48-66)$ & $59(48-67)$ & $60(47-70)$ & -1 & 0.164 \\
\hline ASA 1-3 & 224 & 239 & 293 & $\mathrm{n}=756,95.5 \%$ & $\mathrm{n}=217,85.8 \%$ & $-9.7 \%$ & \multirow[t]{2}{*}{$<0.001$} \\
\hline ASA 4-5 & 6 & 15 & 15 & $\mathrm{n}=36,4.5 \%$ & $\mathrm{n}=36,14.2 \%$ & $+9.7 \%$ & \\
\hline \multicolumn{8}{|c|}{ Unplanned Admissions } \\
\hline -Total & 43 & 30 & 45 & $14.9 \%$ & $51,20.2 \%$ & $+5.3 \%$ & 0.063 \\
\hline$-I C U$ & 32 & 28 & 28 & $11.1 \%, 88$ & $28,11.1 \%$ & - & 1.0 \\
\hline -Ward & 11 & 2 & 17 & $3.8 \%, 30$ & $23,9.1 \%$ & $+5.3 \%$ & 0.001 \\
\hline $\begin{array}{l}\text { Emergency } \\
\text { Operation }\end{array}$ & 32 & 23 & 39 & $11.9 \%$ & $43,17.0 \%$ & $+5.1 \%$ & 0.042 \\
\hline Elective & 183 & 213 & 252 & $81.8 \%$ & $198,78.3 \%$ & $-3.5 \%$ & 0.232 \\
\hline Mortality & 11 & 14 & 11 & $4.5 \%$ & $13,5.1 \%$ & $+0.6 \%$ & 0.828 \\
\hline Preop Stay & $3(0-7)$ & $3(0-7)$ & $2(0-6)$ & $3(0-7)$ & $2(1-6)$ & -1 & 0.177 \\
\hline Postop Stay & $6(1-10)$ & $5(1-10)$ & $3(1-8)$ & $5(1-9)$ & $4(1-7)$ & -1 & 0.504 \\
\hline Total Stay & $11(2-18)$ & $11(1-18)$ & $8(1-14)$ & $10(1-16)$ & $7(2-14)$ & -3 & 0.920 \\
\hline $\begin{array}{l}\text { Heart } \\
\text { Surgery }\end{array}$ & 100 & 100 & 104 & $38.4 \%$ & $90,35.6 \%$ & $-2.8 \%$ & $\mathrm{p}>0.05$ \\
\hline $\begin{array}{l}\text { Vascular } \\
\text { Surgery }\end{array}$ & 52 & 48 & 47 & $18.6 \%$ & $70,27.7 \%$ & $+9.1 \%$ & 0.002 \\
\hline $\begin{array}{l}\text { Venous } \\
\text { Surgery }\end{array}$ & 41 & 36 & 64 & $17.8 \%$ & $47,18.6 \%$ & +0.8 & $\mathrm{p}>0.05$ \\
\hline $\begin{array}{l}\text { Vascular } \\
\text { Access }\end{array}$ & 37 & 70 & 93 & $25.3 \%$ & $46,18.2 \%$ & $+7.1 \%$ & 0.021 \\
\hline
\end{tabular}


Table 3 Type of surgeries with the need of postoperative intensive care at cardiovascular intensive care unit.

\begin{tabular}{|c|c|c|c|c|}
\hline & 2017 & 2018 & 2019 & 2020 \\
\hline \multicolumn{5}{|l|}{ Heart Surgery } \\
\hline Thoracic Aorta & 5 & 3 & 10 & 6 \\
\hline -Asc Aorta repl. & 1 & 2 & 1 & 2 \\
\hline -Asc. + arc. aorta repl. & - & - & 2 & - \\
\hline -Asc.aorta repl. $+M V R$ & - & - & 1 & - \\
\hline -Wheat procedure & 2 & - & 5 & 2 \\
\hline -Wheat proc. $+M V R+C A B G$ & 1 & - & - & - \\
\hline -Benthall de Bono proc. & 1 & 1 & - & 1 \\
\hline -David proc. & - & - & 1 & - \\
\hline -Desc. aorta repl. & - & - & - & 1 \\
\hline CABG & 65 & 64 & 68 & 66 \\
\hline -On-pump CABG & 65 & 61 & 24 & 15 \\
\hline -Off-pump CABG & - & 3 & 26 & 51 \\
\hline CABG + Valve Surgery & 4 & 12 & 10 & 6 \\
\hline$-C A B G+A V R$ & 3 & 2 & 4 & 1 \\
\hline$-C A B G+M V R$ & 1 & 6 & 5 & 4 \\
\hline$-C A B G+A V R+M V R$ & - & 3 & 1 & 1 \\
\hline$C A B G+\operatorname{Tr} A$ & - & 1 & - & - \\
\hline Valve Surgery* & 16 & 13 & 11 & 8 \\
\hline$-A V R$ & 5 & 4 & 4 & 3 \\
\hline$-M V R$ & 7 & 6 & 5 & 4 \\
\hline$-A V R+M V R$ & 4 & 3 & 2 & 1 \\
\hline ASD & 3 & 1 & - & 1 \\
\hline Myxoma & 2 & 1 & 1 & 1 \\
\hline pericardial effusion & 5 & 6 & 4 & 2 \\
\hline Total & 100 & 100 & 104 & 90 \\
\hline \multicolumn{5}{|l|}{ Vascular Surgery } \\
\hline Aorto/ilio-femoral surgery & 9 & 8 & 6 & 11 \\
\hline$-E V A R$ & 5 & 5 & 1 & 2 \\
\hline -Aortoilio/femoral bypass & 4 & 3 & 5 & 9 \\
\hline Popliteal Artery Aneurysm & 3 & 1 & 4 & 2 \\
\hline Femoro-Popliteal Bypass & 5 & 4 & 11 & 13 \\
\hline Embollectomy & 10 & 8 & 13 & 22 \\
\hline Vascular Repair & 25 & 11 & 10 & 15 \\
\hline Surgical Access for TAVI & 0 & 16 & 3 & 7 \\
\hline Total & 52 & 48 & 47 & 70 \\
\hline
\end{tabular}

(ASD: atrial septal defect, Asc.: ascending, arc.:arcus, AVR: aortic valve replacement, CABG: coronary bypass grafting, desc:descending, EVAR: endovascular aneurysm repair, MVR:mitral valve replacement, TrA: tricuspit anulloplasty repl.:replacement, proc:procedure)

*TrA are omitted 
Table 4 Performed tests

\begin{tabular}{|l|c|c|c|c|}
\hline \hline Computed Tomography & $\mathbf{2 0 1 8}$ & $\mathbf{2 0 1 9}$ & $\mathbf{2 0 2 0}$ \\
\hline -Out-patient & $\mathbf{2 0 1 7}$ & 49 & 43 & 15 \\
\hline -In-hospital & 13 & 16 & 28 & 33 \\
\hline $\begin{array}{l}\text { Pneumonia among In- } \\
\text { hospital patients }\end{array}$ & 35 & 33 & 2 & 68 \\
\hline \begin{tabular}{l} 
PCR tests for COVID-19** \\
\hline
\end{tabular}
\end{tabular}

\begin{tabular}{|r|c|c|c|}
\hline & Tests count (n) & Patient (n) & Positive Patients (n) \\
\hline Total & 474 & 344 & 6 \\
\hline -ICU & 45 & 37 & 4 \\
\hline -In-hospital & 390 & 269 & 1 \\
\hline \% out-patient & 39 & 38 & \\
\hline
\end{tabular}

*:3 of them reported having signs of COVID-19 on computed tomography.

**: The tests obtained by other clinics (cardiology, emergency unit) to our patients at admission are not included.

(PCR: polymerase chain reaction)

\section{HEART SURGERY:}

The diagnosis of patients who underwent thoracic aorta replacement in 2017, 2018, 2019, and 2020 was aortic aneurysm, except for patients operated for Sandford type A dissection $(\mathrm{n}=3,2,3$, and 2, respectively).

The patients who underwent heart valve surgery in 2017, 2018, 2019, and 2020 were diagnosed with aortic valve endocarditis $(\mathrm{n}=1,2,1$, and 1 , respectively), mitral valve endocarditis $(n=0,4,3$, and 0 , respectively), aortic and mitral valve endocarditis ( $\mathrm{n}=3,0,1$, and 0 , respectively), ischemic mitral insufficiency ( $\mathrm{n}=1,3,3$, and 2 , respectively), and mitral chord rupture $(\mathrm{n}=1,0,1$, and 0 , respectively). For the remaining patients, the indications for valve replacement were romatismal valve insufficiency or stenosis $(\mathrm{n}=15,16,13$, and 11 , respectively). Almost half $(47.5 \% ; \mathrm{n}=19)$ the patients who died in the heart surgery group were unplanned admissions. Of these, 11 were first admitted to the ICU. More than a third $(35 \% ; \mathrm{n}=14)$ of the deaths in the heart surgery group were emergency operations. The results of the heart surgical patients are presented in Table 5.

When the cases that underwent open heart surgery were examined, the cardiac risk scores ranged between 0 and 21. An increase in the patients with a cardiac risk score $\geq 5$ and ASA score $\geq 4$ was observed in the "new normal" period ( $\mathrm{p}=.040 ; \mathrm{p}<.001$, respectively). A significant reduction in postoperative stay was found in the heart surgery group $(\mathrm{p}=.025)$.

Compared to the pre-pandemic period, in the "new normal" period, among the cases undergoing CABG, the number of off-pump cases increased significantly $(\mathrm{p}<.001)$.

A total of 48 heart surgery cases in the first half and 42 cases in the second half of the "new normal" period were operated on. Of these, $20.8 \%(\mathrm{n}=10)$ of the admissions in the first half and $14.2 \%(\mathrm{n}=6)$ of the admissions in the second half were unplanned admissionss $(\mathrm{p}=.417)$. Emergency operations represented $14.5 \%(n=7)$ of the operations during the first half of the "new normal" period and $2.3 \%(\mathrm{n}=1)$ in the second half $(\mathrm{p}=.042)$, while $79.1 \%(\mathrm{n}=38)$ of the operations in the first half and $85.7 \%(\mathrm{n}=36)$ in the second half were elective cases $(\mathrm{p}=.417)$. Figure 1 shows the number of cases operated on and the distribution of unplanned admissions during the "new normal" period.
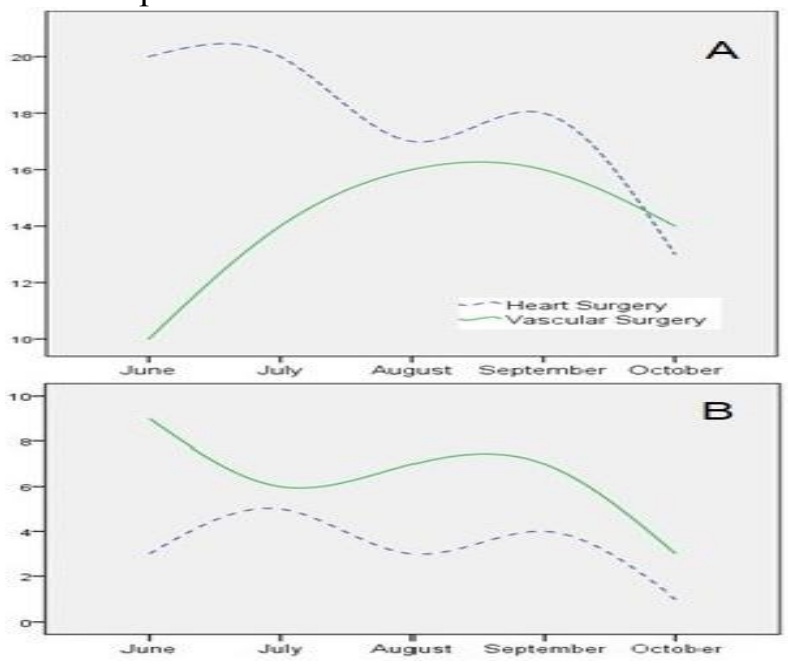

Figure 1: A: The count of all operations, B: The unplanned admissions of the Heart Surgery and Vascular Surgery groups among months during 2020, the "new normal" period 
Table 5: Features of Heart Surgery Group

\begin{tabular}{|c|c|c|c|c|c|c|c|c|}
\hline & 2017 & 2018 & 2019 & 2017-2019* & $\begin{array}{c}2020 \\
(\mathrm{n})\end{array}$ & $\begin{array}{c}2020 \\
\%\end{array}$ & Differance & $p$ \\
\hline Age & $61(52-68)$ & $63(54-69)$ & $61(52-66)$ & $62(53-68)$ & $59(52-70)$ & & $-1.5 \%$ & 0.361 \\
\hline Female & 28 & 34 & 37 & $32.6 \%$ & 25 & $27.8 \%$ & $-4.8 \%$ & \multirow[t]{2}{*}{0.390} \\
\hline Male & 72 & 66 & 67 & $67.4 \%$ & 65 & $72.2 \%$ & $+4.8 \%$ & \\
\hline ASA 1-3 & 95 & 92 & 93 & 280 (92.1\%) & 70 (77.8\%) & & $-14.3 \%$ & \multirow[t]{2}{*}{$<0.001$} \\
\hline ASA 4-5 & 5 & 8 & 11 & 24 (7.9\%) & $20(22.2 \%)$ & & $+14.3 \%$ & \\
\hline CRS $<5$ & 85 & 72 & 81 & $238 \% 82.4$ & 63 & 71.6 & $-10.8 \%$ & \multirow[t]{2}{*}{0.040} \\
\hline$C R S \geq 5$ & 10 & 22 & 19 & $51 \% 17.6$ & 25 & $28.4 \%$ & $+10.8 \%$ & \\
\hline \multicolumn{9}{|l|}{$\begin{array}{l}\text { Unplanned } \\
\text { admission }\end{array}$} \\
\hline -Total & 22 & 22 & 28 & $23.6 \%$ & 16 & $17.8 \%$ & $-5.8 \%$ & 0.272 \\
\hline -Ward & 2 & 2 & 8 & $3.9 \%$ & 5 & $5.6 \%$ & $+1.7 \%$ & 0.510 \\
\hline$-I C U$ & 20 & 20 & 20 & $19.7 \%$ & 11 & 12.2 & $-7.5 \%$ & 0.103 \\
\hline $\begin{array}{l}\text { Emergency } \\
\text { Operation }\end{array}$ & 12 & 6 & 14 & $10.5 \%$ & 8 & $8.9 \%$ & $-1.6 \%$ & 0.651 \\
\hline $\begin{array}{l}\text { Elective } \\
\text { Patients }\end{array}$ & 76 & 77 & 74 & $74.7 \%$ & 74 & $82.2 \%$ & $+7.5 \%$ & 0.138 \\
\hline Mortality & 10 & 12 & 9 & $10.2 \%$ & 9 & $10 \%$ & $-0.2 \%$ & 0.957 \\
\hline Preop stay & $6(4-8)$ & $6(4-9.75)$ & $5(3-8)$ & $6(4-8.75)$ & $5(3-9)$ & & -1 & 0.636 \\
\hline Postop stay & $9(6-12)$ & $8(6-11)$ & $8(6-10)$ & $8(6-11)$ & $7(5-10,25)$ & & -1 & 0.025 \\
\hline Total stay & 15 (12-19) & $15(12-22.7)$ & 13 (11-19) & $14(11.25-20)$ & 13.5 (10-19) & & $-0,5$ & 0.188 \\
\hline
\end{tabular}

CRS: The Cardiac Risk Score based on EuroSCORE

*: the pre-pandemic period, values obtained from the patients between 2017-2019 as a single group

Table 6 Features of Vascular surgery Group

\begin{tabular}{|c|c|c|c|c|c|c|c|c|}
\hline 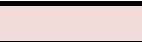 & 2017 & 2018 & 2019 & 2017-2019* & $2020(n)$ & $2020(\%)$ & Differance & $\mathrm{p}$ \\
\hline Age & $59(41-73)$ & $70(54-77)$ & $63(50-70)$ & $63(50-73)$ & $66(48-75)$ & & +3 & 0.381 \\
\hline Female & 17 & 12 & 14 & $29.3 \%$ & 24 & $34.3 \%$ & $+5 \%$ & \multirow[t]{2}{*}{0.453} \\
\hline Male & 35 & 36 & 33 & $70.7 \%$ & 46 & $65.7 \%$ & $-5 \%$ & \\
\hline ASA 1-3 & 51 & 41 & 43 & $91.8 \%$ & $80 \%(\mathrm{n}=56)$ & & $-11.8 \%$ & \multirow[t]{2}{*}{0.022} \\
\hline ASA 4-5 & 1 & 7 & 4 & $8.2 \%$ & $20 \%(\mathrm{n}=14)$ & & $+11.8 \%$ & \\
\hline $\begin{array}{l}\text { Unplanned } \\
\text { admission }\end{array}$ & & & & & & & & \\
\hline -total & 19 & 8 & 16 & 29.3 & 32 & $45.7 \%$ & $+16.4 \%$ & 0.017 \\
\hline -ward & 8 & 0 & 8 & $10.9 \%$ & 15 & $21.4 \%$ & $+10.5 \%$ & 0.038 \\
\hline$-\mathrm{ICU}$ & 11 & 8 & 8 & $18.4 \%$ & 17 & $24.3 \%$ & $+5.9 \%$ & 0.311 \\
\hline $\begin{array}{l}\text { Emergency } \\
\text { Operation }\end{array}$ & 19 & 9 & 15 & $29.3 \%$ & 31 & $44.3 \%$ & $+15 \%$ & 0.029 \\
\hline $\begin{array}{l}\text { Elective } \\
\text { patients }\end{array}$ & 31 & 38 & 31 & $68 \%$ & 35 & $50 \%$ & $-18 \%$ & 0.010 \\
\hline Mortality & 1 & 2 & 2 & $3.4 \%$ & 4 & $5.7 \%$ & $+2.3 \%$ & 0.424 \\
\hline Preop stay & $1(0-6)$ & $3(1.5-8)$ & $3.5(1.25-7)$ & $3(1-6.5)$ & $2(1-7)$ & & -1 & 0.874 \\
\hline Postop stay & $5(2-8.75)$ & $8(5-12)$ & $5(3-10.75)$ & $6(3.5-10)$ & $5(3-7)$ & & -1 & 0,220 \\
\hline Total stay & $9(3-15)$ & $13(8-18)$ & $\begin{array}{c}10.5(7.25- \\
17.5)\end{array}$ & $11(6-16)$ & $9(5-15)$ & & -2 & 0,357 \\
\hline
\end{tabular}

\footnotetext{
*: the pre-pandemic period, values obtained from the patients between 2017-2019 as a single group
} 


\section{VASCULAR SURGERY}

The diagnoses of patients who underwent vascular surgery during 2017-2020 were examined. Among those who underwent abdominal aortic surgery in 2017, 2018, 2019, and 2020, 18 of 34 cases $(5,5,2$, and 6 respectively) had aneurysms at the abdominal aortic-iliac level and 9 (1, 2, 1, and 5 respectively) were ruptured. The remaining 16 cases $(\mathrm{n}=4,3,4$, and 5 , respectively) were operated on due to atherosclerotic occlusive disease. The cases treated with femoropopliteal bypass were operated on due to atherosclerotic occlusive disease, while the vascular injury cases were operated on due to iatrogenic or traumatic vascular injury. Unplanned admissions occurred in $77.8 \%(n=7)$ of the patients who died in the vascular surgery group, of whom 5 were first admitted to the ICU. Seven of the nine patients who died were operated on as an emergency.

The results of the vascular surgical patients are shown in Table 6. In the "new normal" period, increases in ASA score $\geq 4$, total unplanned admissions, unplanned ward admissions, and emergency operations were observed $(\mathrm{p}=.022, \mathrm{p}=$ $.017, \mathrm{p}=.038$, and $\mathrm{p}=.029$, respectively). The elective procedure rate decreased $(\mathrm{p}=.010)$.

In the first half of the "new normal" period, 32 vascular surgery cases were operated on, and 38 were operated on in the second half. Of these, $65.6 \%(\mathrm{n}=$ 21 ) of the admissions in the first half and $28.9 \%$ ( $n=$ $11)$ in the second half were unplanned admissions ( $\mathrm{p}=$ $.002)$. Emergency operations represented $62.5 \%(\mathrm{n}=$ $20)$ of the operations in the first half and $28.9 \%(\mathrm{n}=$ $11)$ in the second half $(\mathrm{p}=.004)$, while $31.2 \%(\mathrm{n}=10)$ of the operations in the first half and $65.7 \%(n=25)$ in the second half were elective cases $(p=.003)$. Figure 1 shows the number of cases operated on and the distribution of unplanned admissions during the "new normal" period.

\section{DISCUSSION}

In this study, we compared the results of the "new normal" period with previous years, finding an overall increase in emergency operations, vascular surgical procedures, and ASA scores. The rate of patients undergoing vascular surgical procedures who needed postoperative ICU care increased, and preoperative risk assessment scores increased significantly in patients undergoing vascular and heart surgery during the "new normal" period. A trend toward off-pump CABG was observed, and postopperative hospital stays were shorter than previous years. During the first half of the "new normal" period, significantly more emergency heart and vascular surgical procedures were performed compared with the second half. CT scans increased more than twofold compared to previous years. Detected pneumonia also increased with the addition of COVID-19 infected patients.
Planning of adult cardiovascular surgery during and beyond the pandemic is of crucial importance. As the same resources are needed to care for patients with COVID-19, cardiovascular surgery has been significantly affected during the pandemic, especially during the infection surges. Opinions and recommendations for cardiac surgery or vascular surgery practice during the pandemic have been published (5-8). Additionally, considering the crucial importance of ICU capacity during the COVID-19 pandemic, calculators and risk models for estimating intensive care use following surgery have also emerged (9). Cardiac surgical cases reduced by $75 \%$ during the surge of the pandemic worldwide.(10) Treatment procedures during the pandemic have been investigated previously, and although some clinics continued elective surgery during the lockdown, a reduction in operations was observed $(1,11)$. It has been estimated that 28 million cases globally were cancelled during the 12-week peak of the pandemic in spring 2020 (12). Millions of patients are still waiting for elective surgical procedures (13).

Risk calculations for patients on a waiting list for cardiac surgery or tools specifically for planning after the expected resumption of elective surgery after the pandemic are recommended $(14,15)$. If patients awaiting heart surgery are operated on over 1 month, a $216 \%$ or $263 \%$ increase in workload has been calculated based on data from large-volume centers (16). The backlog of patients with postponed operations is expected to be resolved between one and eight months after returning to normal (16). However, changes in patient characteristics for the "new normal" period or the real workload after lifting of the restrictions are unknown. Although post-pandemic changes and plans are being discussed, COVID-19 has been brought under control only in some high-income countries, and the problem continues for most of the world. A new surge has occurred in our country in spring 2021.

A three-phase resumption of cardiac surgical programs is advised whereby patients with urgent surgical needs will be treated at the first stage, followed by patients less likely to require prolonged ICU and hospital stays, and the third phase signifies full resumption of outpatient services (17). In our experience, direct resumption of the third phase occurred after "flattening of the curve" in summer 2020. A 75-day lockdown during which elective procedures were postponed augmented the proportion of patients with cardiac risk scores $\geq 5$ by $10 \%$ in the "new normal" period compared to previous years (Table 5). The increase in ASA 4 and 5 patients in both the heart and the vascular surgical groups by more than $10 \%$ ( $\mathrm{p}<.001$ and $\mathrm{p}=.022$, respectively) compared to previous years, demonstrates that life-threatening conditions were more frequent in the "new normal" era (Tables 5-6) (18). More unplanned admissions and emergency operations occurred for vascular surgical patients $(\mathrm{p}=.017$ and $\mathrm{p}=.029$, respectively) compared 
to previous years. The workload increased at the beginning of the "new normal" period as demonstrated by the increase in emergency heart surgery and vascular surgery in the first half of the "new normal" period compared to the second half $(\mathrm{p}=.042$ and $\mathrm{p}=$ .002 , respectively) This should be considered when planning for postponed elective procedures in the "new normal" period. The se changes may differ according to the center's volume or geographic location, as the characteristics of the surge and drop in cases during the pandemic was not the same even in neighboring cities (19).

The observed fall in the number of cardiac surgical operations, unplanned admissions, and emergency operations compared to previous years might be explained by "survivorship bias." We hypothesized that vascular surgical patients came to the hospital with more emergent clinics; however, it is possible that cardiac surgical patients did not survive. A $43 \%$ reduction in hospitalizations for acute cardiovascular causes and a threefold increase in out-of-hospital cardiac arrests were observed during the COVID-19 pandemic (20). Cardiac mortality increased during the early phase of the pandemic, especially among elderly patients, hypertensive patients, and male diabetic patients (21).

Different surgical strategies to shorten hospitalization during the pandemic have been reported (22). In our institution, the choice to perform off-pump surgical procedures resulted in shortened hospital stays for heart surgery patients during the postoperative period.

High mortality, high prevalence of coagulopathy and thrombosis, and postoperative respiratory failure have been associated with preoperative COVID-19 infection among patients requiring cardiac surgery (2325). However, no guideline dictates the testing frequency and method for preoperative cardiovascular patients (1). In our clinic, liberal use of thorax CT scanning and repeated PCR tests for all hospitalized patients have been used to prevent in-hospital spread of the infection and for preoperative screening. The number of CT scans performed in the "new normal" period increased more than twofold compared to each year of the pre-pandemic era. A positive test was present among $1.26 \%(\mathrm{n}=6)$ of the patients who received PCR tests (Table 4), and 3 heart surgical procedures were cancelled due to COVID-19 infection. Three cases of patients with COVID-19 pneumonia were diagnosed using CT, which was a twofold increase in cases compared to the pre-pandemic period (Table 4). It has been reported that with careful patient assessment, similar rates of adverse outcomes with the pre-pandemic era have been achieved even during the pandemic (26). The mortality rates did not change between our groups. Only one vascular surgical patient was diagnosed with COVID-19 infection, and the condition could not be attributed to COVID-19-related coagulopathy.

\section{LIMITATIONS OF THE STUDY}

The present study has several limitations. A retrospective study has inherent shortcomings. Among the vascular surgical patients, the vascular repair and the vascular access for transcatheter aortic valve replacement subgroups do not represent patients with peripheral vascular disease. However, they were included in the study, as they inevitably impact surgical workload. Moreover, the symptom duration of the heart and vascular surgical patients could not be demonstrated. Reaching symptomatic patients who did not visit a health care facility might be feasible and could reduce the collateral damage of COVID-19. Another limitation is the use of the national CRS based on the EuroSCORE, as it does not include several of the original score's parameters and might underestimate patient risk compared to the EuroSCORE.

\section{CONCLUSION}

In conclusion, increased admissions of urgent cases are to be expected at the initiation of the "new normal" period. Inability to diagnose patients or insufficient treatment of diagnosed patients during lockdown may have resulted in this outcome. Additionally, patients operated on in the "new normal" period had a higher operative risk, which, could increase health care facilities' workload without staged resumption of surgical care.

\section{ACKNOWLEDGEMENTS}

The authors declared no potential conflicts of interest with respect to the research, authorship, and/or publication of this article.

The authors received no financial support for the research, authorship, and/or publication of this article.

Ethics Committee Approval: Ethical approval was obtained.KOÜ.Tıp Fak. (80418770-730.99/81972)

Conflict of Interest: There is no conflict of interest.

Funding: There is no financial support.

Informed Consent: This a retrospective study

\section{REFERENCES:}

1. Idhrees M, Bashir M, Mousavizadeh M, Hosseini S. International study on impact of COVID-19 on cardiac and thoracic aortic aneurysm surgery. J Card Surg. 2020; 
2. COVIDSurg_Collaborative. Mortality and pulmonary complications in patients undergoing surgery with perioperative SARS-CoV-2 infection: an international cohort study. Lancet. Jul 4 2020;396(10243):27-38.

doi:10.1016/s0140-

6736(20)31182-x

3. Arrkan AA. OP ID- 840 Management of Cardiovascular Surgery Patients During Pandemic Process. E J Cardiovasc Med. 2020;8(1 (Supplement)):253.

4. Roques F, Nashef SA, Michel P, Gauducheau E, de Vincentiis C, Baudet E, et al. Risk factors and outcome in European cardiac surgery: analysis of the EuroSCORE multinational database of 19030 patients. Eur J Cardiothorac Surg. Jun 1999;15(6):816-22; discussion 22-3. doi:10.1016/s1010-7940(99)00106-2 5. Mavioğlu HL, Ünal EU, Aşkın G, Küçüker ŞA, Özatik MA. Perioperative planning for cardiovascular operations in the COVID-19 pandemic. Turk Gogus Kalp Damar Cerrahisi Derg. 2020;28(2):236.

6. Haft JW, Atluri P, Ailawadi G, Engelman DT, Grant MC, Hassan A, et al. Adult cardiac surgery during the COVID-19 pandemic: a tiered patient triage guidance statement. Ann Thorac Surg. 2020;110(2):697-700.

7. Günertem E, Akay T, Sargin M, Erdil N, Uğuz E, Aslim E, et al. Paradigm shifts in terms of vascular emergencies during COVID-19 outbreak: An Expert Opinion report. Turk J Vasc Surg. 2020;29(3):208-21.

8. Özker E, Erkin A, Aslan HM, Kurtoğlu T, Çayır MÇ, Akay T, et al. Wound treatment strategies during COVID-19 pandemic: An expert opinion. Turk J Vasc Surg. 2020;30(2)

9. STS. The Society of Thoracic Surgeons Resource Utilization Tool for Cardiac Surgery. The Society of Thoracic Surgeons Accessed 10/05/2021, https://www.sts.org/resources/resource-utilization-tool 10.Gaudino M, Chikwe J, Hameed I, Robinson NB, Fremes SE, Ruel M. Response of Cardiac Surgery Units to COVID-19: An Internationally-Based Quantitative Survey. Circulation. Jul 21 2020;142(3):300-2.

doi:10.1161/circulationaha.120.047865

11.Dias RR, Santiago JAD, Madrini Junior V, Mady C, Jatene FB. Impact of COVID-19 Pandemic in a Brazilian High-Volume Aortic Center. Braz J Cardiovasc Surg. 2021;36(2):145-9.

12.Nepogodiev D, Omar OM, Glasbey JC, Li E, Simoes JF, Abbott TE, et al. Elective surgery cancellations due to the COVID-19 pandemic: global predictive modelling to inform surgical recovery plans. Br J Surg. 2020;107(11):1440-9.

13.Osman F, Caplin N, Bashir M. COVID-19: The rising cost of cardiac surgery and disease. J Card Surg. 2021;36(5):1593-6.

doi:https://doi.org/10.1111/jocs.15206

14.Rexius H, Brandrup-Wognsen G, Nilsson J, Odén A, Jeppsson A. A Simple Score to Assess Mortality Risk in Patients Waiting for Coronary Artery Bypass
Grafting. Ann Thorac Surg. 2006/02/01/ 2006;81(2):577-82.

doi:https://doi.org/10.1016/j.athoracsur.2005.08.032 15.Joshi D, Jalali A, Whipple T, Rehman M, Ahumada LM. "P3": an adaptive modeling tool for post-COVID19 restart of surgical services. JAMIA Open. 2021;4(2)doi:10.1093/jamiaopen/ooab016

16.Salenger R, Etchill EW, Ad N, Matthew T, Alejo D, Whitman G, et al. The Surge After the Surge: Cardiac Surgery Post-COVID-19. Ann Thorac Surg. 2020/12/01/ 2020;110(6):2020-5. doi:https://doi.org/10.1016/j.athoracsur.2020.04.018 17.Hassan A, Arora RC, Lother SA, Adams C, Bouchard D, Cook R, et al. Ramping Up the Delivery of Cardiac Surgery During the COVID-19 Pandemic: A Guidance Statement From the Canadian Society of Cardiac Surgeons. Can J Cardiol. Jul 2020;36(7):113943. doi:10.1016/j.cjca.2020.04.030

18.Doyle DJ, Garmon EH. American Society of Anesthesiologists classification (ASA class). StatPearls [Internet] https://www ncbi nlm nih gov/books/NBK441940. 2018;

19.Benedetto U, Goodwin A, Kendall S, Uppal R, Akowuah E. A nationwide survey of UK cardiac surgeons' view on clinical decision making during the coronavirus disease 2019 (COVID-19) pandemic. J Thorac Cardiovasc Surg. 2020;160(4):968-73. doi:10.1016/j.jtcvs.2020.05.016

20.Lai PH, Lancet EA, Weiden MD, Webber MP, Zeig-Owens R, Hall CB, et al. Characteristics associated with out-of-hospital cardiac arrests and resuscitations during the novel coronavirus disease 2019 pandemic in New York City. JAMA Cardiol. 2020;5(10):1154-63.

21.Wadhera RK, Shen C, Gondi S, Chen S, Kazi DS, Yeh RW. Cardiovascular Deaths During the COVID19 Pandemic in the United States. J Am Coll Cardiol. 2021;77(2):159-69. doi:10.1016/j.jacc.2020.10.055

22.Mejia OAV, Borgomoni GB, Lasta N, Okada MY, Gomes MSB, Foz M, et al. Safe and effective protocol for discharge 3 days after cardiac surgery. Sci Rep. Apr 26 2021;11(1):8979. doi:10.1038/s41598-02188582-0

23.Salna M, Polanco A, Bapat V, George I, Argenziano M, Takeda K. A case of coronavirus disease 2019 (COVID-19) presenting after coronary artery bypass grafting. J Thorac Cardiovasc Surg. 2020;160(4):e193-e5.

24.Akowuah E, Benson RA, Caruana EJ, Chetty G, Edwards J, Forlani S, et al. Early outcomes and complications following cardiac surgery in patients testing positive for coronavirus disease 2019: An international cohort study. J Thorac Cardiovasc Surg. 2021/04/03/

2021;doi:https://doi.org/10.1016/j.jtcvs.2021.03.091

25.Hussain A, Khalil A, Kolvekar P, Gupta P, Kolvekar S. COVID-19 related mortality in postoperative cardiac surgical patients. J Cardiothorac Surg. 2021;16(1):1-4. 
26.Parcha V, Kalra R, Glenn AM, Davies JE, Kuranz $\mathrm{S}$, Arora $\mathrm{G}$, et al. Coronary artery bypass graft surgery outcomes in the United States: Impact of the coronavirus disease 2019 (COVID-19) pandemic.

JTCVS Open. 2021/03/30/

2021;doi:https://doi.org/10.1016/j.xjon.2021.03.016 